\title{
PAPILOMA ESCAMOSO BUCAL - RELATO DE DOIS CASOS
}

Deniton Cezar TAGLIARI, Cassiano Lima CHAIBEN, Maria Helena Martins TOMMASI, Iran VIEIRA, Antonio Adilson Soares de LIMA

O papiloma escamoso bucal (PEB) é uma lesão proliferativa benigna do epitélio escamoso estratificado. Clinicamente, esta lesão se apresenta sob a forma de um nódulo exofítico mole, indolor, pedunculado ou séssil e com inúmeras projeções superficiais. A etiologia do PEB está associada ao HPV subtipos 6 e 11. Sua ocorrência em boca é relativamente incomum. O objetivo deste trabalho será relatar dois casos de PEB. No caso 1, paciente do sexo feminino apresentava uma lesão indolor, ligeiramente esbranquiçada, séssil e de aspecto verrucoso no soalho bucal. No caso 2, paciente do sexo feminino exibia duas lesões esbranquiçadas similares na região do pilar amigdaliano, indolores, sésseis e com aproximadamente dois anos de evolução. Nos dois casos, as lesões foram totalmente removidas por meio de biopsia excisional e encaminhadas para exame histopatológico. O diagnóstico do PEB foi confirmado pela histopatologia que revelou fragmento de lesão exibindo proliferação epitelial de aspecto digitiforme com áreas centrais de tecido conjuntivo. No tecido epitelial havia áreas de hiperceratose e a presença de coilocitose. O PEB é uma lesão com características próprias, mas que pode ser confundido com outras lesões bucais esbranquiçadas. Neste contexto, o estudo das características histopatológicas continua sendo o recurso mais recomendado para diagnóstico.

Palavras-chave: Mucosa bucal; Papiloma; Proliferação Celular; Papillomavirus Humano. 